\title{
Collaboration of Teachers and Parents through Game-based Simulation and Contextual Games to Cultivate Savings Interest in SD Sumbersari III Kota Malang
}

\author{
Sri Umi Mintari. W' ${ }^{1}$ Rizza Megasari², Dian Rachmawati ${ }^{3}$ \\ ${ }^{1}$ Developmental Economic Department UM, Malang Indonesia, $\square$ (e-mail) sriumi_mintarti@yahoo.co.id \\ ${ }^{2}$ Developmental Economic Department UM, Malang Indonesia, $\triangle$ (e-mail) rizza.megasari.fe@um.ac.id \\ ${ }^{3}$ Developmental Economic Department UM, Malang Indonesia, $\square$ (e-mail) dian.rachmawati.fe@um.ac.id
}

\begin{abstract}
Economic education in the field of finance is very important to do from early childhood as such education will be useful in adulthood. This research was conducted at SD Negeri Sumbersari II, in the Lowokwaru district of Malang city. The research subjects are teachers, students and parents of students. The purpose of this study to discover how the motivation of students in saving can be developed. The type of research is qualitative, data retrieval is done by observation, FGD, and in-depth interview. Data analysis is done in three steps: data reduction, presentation of data, and report. Triangulation of sources is necessary to obtain the validity of research data. The results show that, by playing simulations and games, students are motivated to set aside some of their allowance for savings. Parents play a role too, by introducing the real and contextual world of Banks to their children, they can help motivate children to understand the economic values, especially financial management. Students can consume based on need, not desire. It is recommended to parents to improve their children's economic education, so that they have the skills to manage their finances in the future.
\end{abstract}

Keywords: economic education, FGD, simulation, game, contextual

\section{Introduction}

Economic education in early childhood is very important. As knowledge acquired at an early age is memorable and is always inherent in a child's life, financial lessons in primary and middle school-aged children will provide a good foundation for establishing a vital economic understanding, which in turn will help them manage their finances well and avoid debt problems, bankruptcies, etc. (Greenspan, 2003).

It is to be noted that economic education for children conducted in the family should pay attention to the characteristics of the children and must be tailored to the child's mental condition in order to create a fun learning atmosphere. Economic education, especially in ways of managing money, is very beneficial to children, who, in their later adult years will in turn be responsible in using their income and will be cautious in spending their money. (Lermitte \& Merrit, 2004). Early knowledge of good financial management will be very useful for financial management in adulthood. This is, as Curto, 2009 states, that wrong financial decisions in youth are often expensive in old age. So the skills to manage good finances in an early age, will have results in the future. At old age, they will avoid debt problems when they have good skills in managing money. In educating children, parents are expected not to give much concessions to children, in the sense of not spoiling children, because spoiling children will damage their future (Lawrence, 2003). Children should be given responsibility to manage their allowance. Even though parents are able to provide excess pocket money, children should be given pocket money that are adjusted to their age and needs as this will later influence the habits of children in spending their pocket money. 
Economic education, especially in finance management for elementary school age children can be done in various ways according to the conditions of the children, and can be done at home or at school. Economic education, in this case saving, is highly recommended by the government to be given to children from an early age. Lermitte and Merrit (2004) state that when a child is five or six years of age, it is time for parents to introduce them to the world of money, from the simplest, the value of money (when the child is familiar with the numbers), then introducing to the child that they need money to buy necessities. It is at this point that the parents' role is required, to provide responsibility to children in financial management. Besides that, children should be given the trust and responsibility to manage the allowance that has been given to them. Parents need to give children the freedom to manage their pocket money, but as parents they still need to guard the children in using their allowance. Honesty in the use of finances needs to be emphasized. In the case of saving, parents are expected to set an example for children to set aside some of their income for savings, it does not matter how much. Whenever possible they should take the children to the Bank when they save. Learning directly from parents will be easy for children to follow due to the child's habit to imitate what his parents do. One method of economic education in the family is by "role model", with parents acting as role models for their children.

A contextual approach is necessary for economic education in the family as this approach can assist students in understanding the learning materials. According to Dewey, in essence students will learn well if what they learn relates to what they know. Furthermore, the learning process will be productive if the students are actively involved in learning (Nurhadi, 2004: 8). That is, students will learn well and learning will be productive if the students can relate to what they are learning and are active in the learning.

Learning to save can be done through simulation and games, which can be done by teachers at school. The role of teachers in this case is necessary, because it is often the case that children will be obedient to their teacher first and then to their parents. Thus, the use of simulation and games is suitable to motivate children to save. Interests to save can come from within the students or from without. Simulation and games will make children understand quickly how saving can be done. This will encourage students to save, which in turn will enable students to live frugally. Many research has shown that simulation and games on learning will encourage students to improve their learning activities. For example, the research conducted by Mark.K. (2011) on the benefits of learning using games and simulations to improve student performance in learning. The simulation method is also very useful because by using this method, students are actively involved in the learning so that they can easily absorb and understand the learning materials. This is in line with research conducted by Bulama (2016), which stated that the method of simulation is very effective in improving student performance on doing tasks compared with the lecture method which does not provide students with opportunities to participate in learning. The simulation method, on the other hand, provides opportunities for students to participate in the lesson. It also complies with the demands of curriculum 13, which requires students to be active in learning. Implementation of simulation and games in learning can help students easily absorb the learning materials, quickly understand, and ultimately help them get good learning achievements. Simulation and games in learning is a model that is easy to implement and is easily understood by students. Jindra (2017) observed in their research that simulation and games is an effective tool for learning as it can be used to simulate economic phenomena that occur today. This simulation game can also be called experiential learning. With students' increasing experience, the simulation game can run smoothly, which in turn can help students absorb and understand the learning materials.

The low motivation in children to save is a problem that must be overcome because it will impact on his life as adults later. When a child cannot manage finances from childhood then it is possible when adults will be difficult in the management of finances, may be debilitated or even went bankrupt. From the description above can be seen that the purpose of this study to discover how the motivation of students in saving can be developed. This study looks at the importance of the role of parents in developed the motivation of saving in the management of early childhood. The role of parents in 
economic education in families collaborated with learning in the classroom through contextual learning is very easy for children to understand the importance of saving and priority scale in financial management. Considering the importance of these objectives it is necessary to conduct research with the title "Teachers and Parents Collaboration to instill economic values through simulation and contextbased games to develop interests in saving among students at SD Sumbersari III Malang".

\section{Methods}

This research is qualitative research, which is set to describe phenomena that exist in children at SDN II Sumbersari with regards to their saving activity. The subject of research were students, parents and teachers. Determination of informants was done by purposive sampling after discussion with the teachers. The informants are made up of 18 children, who are from $3^{\text {rd }}$ (6 students), $4^{\text {th }}$ ( 4 students) and 5 th grade (8 students). The data were collected by observations, FGD, and interviews. Observations were made prior to the study, to observe the behavior of students in managing their allowances, judging by the way they bought food in the school canteen. FGDs were conducted to obtain data on the economic education of children in their family, in which data is obtained from the parents. Then, we obtain from the teachers, data related to the use of simulation games in learning. Interviews are used to obtain data about the amount of allowance and its management. Data analysis is done by first sorting the data as needed according to the research objectives. Then, data is presented and reported. Triangulation of resources is done to obtain the validity of the research data.

\section{Results and Discussion}

\section{Results of FGD Implementation}

After parents carry out the FGD during routine student guardian meeting at the end of each school year, the parent is obliged to give encouragement to the child to set aside his allowance for saving. The amount of allowance received by children varies, ranging from IDR2000.00 to IDR10.000,00, which is based on the child's need. From the FGD results, we obtained data that parents provide their children with pocket money depending on the children needs each day. If there is a need for extra pocket money outside the usual daily needs, then parents will add extra pocket money as needed. Of the 18 children the amount of allowance they receive can be seen from the table below.

Table 1 Students allowance

\begin{tabular}{cccc}
\hline No & Allowance & $\begin{array}{c}\text { Number of } \\
\text { Student }\end{array}$ & $\%$ \\
\hline 1. & IDR2.000,00 - IDR3.600,00 & 4 & $23 \%$ \\
\hline 2. & IDR3.600,00 - IDR5.200,00 & 9 & $50 \%$ \\
\hline 3. & IDR5.200,00 - IDR6.800,00 & 1 & $5 \%$ \\
\hline 4. & IDR6.800,00 - IDR8.400,00 & 3 & $17 \%$ \\
\hline 5. & IDR8.400,00 - IDR10.000,00 & 1 & $5 \%$ \\
\hline
\end{tabular}

From the table above we can see that there are 4 children who get an allowance of between IDR2.000,00 to IDR 3,600,00 (23\%). A total of 9 children or $50 \%$ of the children receive an allowance of between IDR 3,600,00 to IDR 5,200. Students who earn an allowance between IDR 5,200.00 to IDR 6,800.00 are $5 \%$ or just one student. There are $17 \%$ of students who receive an allowance of between IDR $6,800.00$ to IDR $8,400.00$, and 1 student or $5 \%$ of students who receive an allowance of between IDR $8,400.00$ to IDR $10.000,00$. 


\section{Implementation of Game and Simulation}

To increase student saving interest is done one of them by simulation of saving to classroom teacher, then when reaching minimum amount IDR 50,000, - then the students will be invited to bank to open account by using identity card (KTP) of each parent. From the allowance received by each child, we observe variation on the amount of their savings. However, the amount of allowance received by students does not affect the amount of their savings. This means that it is not always the case that the highest amount allowance will result in the highest amount of saving. This can be seen in table 2 below.

Table 2: Students Saving

\begin{tabular}{cccc}
\hline No & Saving amount & $\begin{array}{c}\text { Number of } \\
\text { Students }\end{array}$ & $\%$ \\
\hline 1. & IDR500,00 - IDR 1.400,00 & 6 & $33 \%$ \\
\hline 2. & IDR1.400,00 - IDR2.300,00 & 5 & $28 \%$ \\
\hline 3. & IDR2.300,00 - IDR3.200,00 & 2 & $11 \%$ \\
\hline 4. & IDR3.200,00 - IDR4.100,00 & 2 & $11 \%$ \\
\hline 5. & IDR4.100,00 - IDR5.000,00 & 3 & $17 \%$ \\
\hline
\end{tabular}

Table 2 shows that all students save from the allowance they receive. The urge to set aside some of the allowance for savings comes mostly from the students themselves. Of the 18 students, as many as 14 people save because of their own desire after they play the simulation games in class. While 3 people save because of the advice of their parents, and one student saves because of the advice of his brother.

The drive to save from students' own desires are huge, this is because the students feel that saving can help them when they need extra money or when there is an additional need. Student motivation comes after they play simulations and games in school. They play roles as if they were in the bank. For them, playing is fun. Therefore, they are very enthusiastic when they play the simulation of "saving" at the Bank. Similarly, children who often came with their parents to save money at the bank are motivated to save money as well. Thus, learning with contextual approach helps students quickly understand the learning materials because when learning relates to real life, the learning materials will be easily absorbed and understood by students. This is also in accordance with the opinion of Nurhadi (2004) and Kasihani (2002) which stated that students will learn well and productively when they know firsthand what they will learn and when they are given the opportunity to participate in learning. Learning with contextual approach in principle helps teachers to relate the learning materials with the students' real life circumstances. Similarly, as Johnson pointed out, students will learn well when the materials are related to what they know and are familiar with. In turn, this will result in a productive learning process as students are actively involved in the learning. Ultimately, the materials delivered will be easily accepted and understood by the students, who will follow up with what they are learning in class in their real life. Games are useful to motivate children to save. This is because children realize that they have to set aside some of their allowance to save money for later even though they are given the freedom to spend their pocket money in the simulation game.

From what we observed, although children are very enthusiastic to make a purchase, they can control themselves and not getting overly intent in spending their pocket money. This is evidence that economic education, especially in the management of allowance through context-based games in elementary school children can motivate children to save. Saving activities that are done since an early age (no matter how much) can greatly influence the child's later life. This is in accordance with the opinion of Lermitte and Merrit. (2004) as well as Curte (2009) which stated that an early knowledge of good financial management will have an effect on adulthood. Children should be familiarized with the use of their allowance since childhood as these habits will be carried well into the future (Lawrence, 2003). 


\section{Conclusions}

Collaboration of teachers and parents in instilling economic values especially through context-based simulation and games for financial management can motivate children to save. Children can be motivated to save even without direct encouragement of their parents or teachers. The amount of allowance is not an obstacle to save, which means that although the pocket money they receive might be small, the children are still able to set aside some of their allowance to save. We also recommend parents to provide context-based financial management to their children by giving real life examples to their children as parents are role models to their children.

\section{References}

Adyaksa, Majid. (2016). Menumbuhkan Minat Menabung Pada Anak Usia Dini Melalui Perancangan Game Edukasi. Skripsi, Fakultas Ilmu Komputer.

Bello, S. I, Bukar, M,B, I, Bulama. (2016). Effect of simulation techniques and lecture method on students' academic performance in mafoni day secondary school maiduguri, borno state, Nigeria. Journal of Education and Practice, 7(23).

Dolvin, Steven D \& Pyles, Mark K. (2011). The influence of simulation performance on student interest. Journal of Economics and Economic Education Research, 12(3).

Greenspan, A. (2003). The importance of financial and economic education and literacy. Journal of Social Education, 67(1).

Huston, Sandra J. (2010). Measuring Financial Literacy. Financial Literacy Summer 2010, 44(2), 296-316. Retrieved from https://doi.org/10.1111/j.1745-6606.2010.01170.x.

Johnson,E.B. (2002). Contextual Teaching Learning. California: Corwin.Press.Inc.

Kasihani, K.Latief.A, Nurhadi. (2002). Pembelajaran Berbasis CTL. (Contextual Teaching and Learning). Makalah disampaikan pada Kegiatan Sosialisasi CTL untuk dosen-dosen UM . Malang 12 Pebruari 2002.

Lawrence, E.Shapiro. (2003). Mengajarkan Emotional Intelligence Pada Anak. Jakarta: Gramedia Pustaka Utama.

Lermitte, Paul.W \& Meritt, J. (2004). Agar Anak Pandai Mengelola Uang. Jakarta : PT Gramedia Pustaka Utama.

Lusardi, A., Mitchell, O.S., and Curto V. (2009). Financial Literacy Among the Young: Evidence and Implications for Consumer Policy. NBER Working Paper 15352. September 2009. JEL No. D91.

Nurhadi. (2004). Pembelajaran Kontekstual (Contextual Teaching and Learning/CTL) dan penerapannya dalam KBK. Malang: Universitas Negeri Malang.

Peterkova, Jindra. (2017). How to lead economics and business student to creativity with managerial simulation game?. Journal of Economics and Economic Education Research, 18(1).

Putri, Anggraeni Yeni. (2017). Pengaruh Pengetahuan Keuangan dan Pendidikan Keuangan Di Keluarga terhadap pengelolaan Keuangan mahasiswa di Surabaya. Retrieved from http://eprints.perbanas.ac.id/2891/1/ARTIKEL\%20ILMIAH.pdf.

Roberts, James A., and Jones, E. (2001). Money Attitudes, Credit Card Use, and Compulsive Buying Among American College Students. The Journal of Consumer Affairs, 35(21).

Rapih, S. (2016). Pendidikan Literasi Keuangan pada Anak: Mengapa dan Bagaimana?. Scholaria: Jurnal Pendidikan Dan Kebudayaan, 6(2). 